\title{
A GIS Based Approach to Back Trajectory Analysis and Mass Concentration \& Dispositions of Aerosols in Nairobi, Kenya
}

\author{
Zachary Misiani ${ }^{1}$, Yin Lun ${ }^{2}$, Shengjie Niư ${ }^{3}$, Jingjing Lü ${ }^{3}$, Luyao Zhang ${ }^{3}$ \\ ${ }^{1}$ Kenya Meteorological Department, Ministry of Environment \& Forestry, Nairobi, Kenya \\ ${ }^{2}$ Yunnan Academy of Social Sciences, Kunming, China \\ ${ }^{3}$ Key Laboratory of Aerosol-Cloud-Precipitation, China Meteorological Administration, Collaborative Innovation Center on \\ Forecast and Evaluation of Meteorological Disasters, Nanjing University of Information Science and Technology, \\ Nanjing, China \\ Email: zacharymisiani@gmail.com
}

How to cite this paper: Misiani, Z., Lun, Y., Niu, S. J., Lü, J. J., \& Zhang, L. Y. (2019). A GIS Based Approach to Back Trajectory Analysis and Mass Concentration \& Dispositions of Aerosols in Nairobi, Kenya. Journal of Geoscience and Environment Protection, 7, 122-139.

https://doi.org/10.4236/gep.2019.72009

Received: January 8, 2019

Accepted: February 24, 2019

Published: February 27, 2019

Copyright $\odot 2019$ by author(s) and Scientific Research Publishing Inc. This work is licensed under the Creative Commons Attribution International License (CC BY 4.0).

http://creativecommons.org/licenses/by/4.0/

\begin{abstract}
The origins and pathways of atmospheric aerosols in Kenya are examined in Nairobi for the three years (2015-2017) using HYSPLIT model and meteorological data. Aerosol concentrations in Kenya depended on the frequency of the air mass from the northeastern Asian Continent and southeastern Madagascar Island. There was a direct correlation of more pollutants during dry and hot seasons (JJA) of the year. To study the reasons for the seasonal variations, the origins of the air mass flowing to Nairobi were analyzed by backward air mass trajectory analysis. Monthly variations revealed that aerosols are transported from different directions due to variation of winds flowing and peak values were during July because of the increased emissions due to higher temperature and stronger solar radiation during heating, while the lowest value found in April was probably due to rain wash.
\end{abstract}

\section{Keywords}

Source Identification, Aerosol Particles, Mascarene, Azores, St. Helena, Arabia

\section{Introduction}

Atmospheric tropospheric aerosol is the suspension of liquid and solid particles with varying diameter mostly range from a few nanometers to tens of micrometers in the atmosphere. This aerosol plays an important role in solar radiation budget, climate change, hydrology process, air quality and visibility through the 
effect of scattering and absorption of incoming solar energy from the sun (Levy et al., 2007). The atmospheric tropospheric aerosol particles originate from a variety of sources, both from primary and secondary sources, as well as natural or anthropogenic ones. Understanding the importance of these sources for the concentration and chemical composition of particles at different locations is a key question in health (Van Pinxteren et al., 2010) and climate issues (Isaksen et al., 2009), as well as in fundamental atmospheric chemistry studies. The tropospheric aerosol particles in the atmosphere play an important role in meteorological effects (Mahowald et al., 2002; Shao et al., 2006). The meteorological and climatic importance of aerosols includes the absorption and scattering of solar radiation from the sun and the modifications of the optical properties of clouds and snow surfaces (Tegen \& Fung, 1994).

Back trajectory techniques has been widely utilized worldwide for study the source-sinking points and path of aerosols, for example (Jaffe et al., 1999) confirmed that anthropogenic emissions from Asia was having a significance impacts in North America (Zachary et al., 2018) also confirmed that atmospheric aerosols arriving at the ICIPE Mbita mainly depends on the prevailing trade winds which are north-easterlies during wet season which had a big influence on the transportation of trajectory pathways from Arabian Peninsula, while in dry season, the winds were mainly south-easterlies which brought oceanic sea salt aerosols from Indian Ocean and Madagascar Island. From the research, it can be seen that back trajectories aid researchers to understand the origin of the atmospheric aerosols.

Air mass back trajectory analysis was performed as described by (Beukes et al., 2013). Individual hourly back trajectories were compiled with the HYSPLIT 4.8 model, which was developed by the National Oceanic and Atmospheric Administration (NOAA) (Draxler \& Rolph, 2013; Draxler et al., 1998). This model was run with meteorological data of the GDAS archive of the US National Weather Service's National Centre for Environmental Prediction (NCEP) and archived by the Air Resources Laboratory (ARL).

Each hourly arriving back trajectory was calculated for 120 hours (5 days) backwards. An arrival height of $2000 \mathrm{~m}$ was chosen, since Nairobi is at altitude of 1650 meters above sea level and furthermore, the dispersion models are very useful to design strategies to reduce emissions and manage air quality in any given region. The concentration of pollutants varies by wind direction at a receptor (Zhang et al., 2016).

The processes by which atmospheric aerosols are removed from the atmosphere by precipitation (wet removal process) can be divided into two categories namely: in-cloud and below-cloud regimes. In-cloud processes which are governing wet deposition of aerosols include inertial removal by cloud drops, nucleation, and diffusion to cloud drops while below-cloud processes include inertial removal by precipitation and diffusive removal on precipitation (Twomey, 1977). It has been found that in-cloud process is more efficient than below cloud 
due to the presence of the large total surface area of droplets within the cloud compared to raindrops below cloud base (Asman, 1995; Walker et al., 2000).

After laying the basis for this study, a brief analysis of the introduction is presented in section one. Section two documents the methodology used and area of study, while section three describes the discussion of the results. Besides, in the same section, the climatic conditions of the area of study are described. In addition to that, the prominent features are also highlighted. Section four provides summery and conclusions while last section gives the future scope for the study.

This research work presents a review of air-mass back trajectories and their role in air pollution transport. It describes the concept, history, and basic calculation of air trajectories using HYSPLT model, MeteoInfo and Originlab models which is used worldwide. These air masses are responsible for the source and sinking of pollutants depositing in nearby area of interest. Forward and back trajectories trace an air parcel's path back in time and it indicates where the air parcel should be or has been before it arrives the locations where it is analyzed (Ha et al., 2017). Apart from meteorological data, this modal uses also vertical movement of atmospheric circulation as input, and it displays the analysis of the simulation outputs (Stein et al., 2015).

\section{Materials and Methods}

\subsection{Area of Study}

Kenya is situated within the low pressure region of ITCZ of $5^{\circ} \mathrm{N}$ and $5^{\circ} \mathrm{S}$ Figure 1. Nairobi is one of the largest city in Kenya serving as administrative capital. This urban-industrial city is situated on latitudes and longitudes of $1.34^{\circ} \mathrm{S}$ and $36.87^{\circ} \mathrm{E}$ from the equator at an altitude of 1650 meters above sea level neighboring

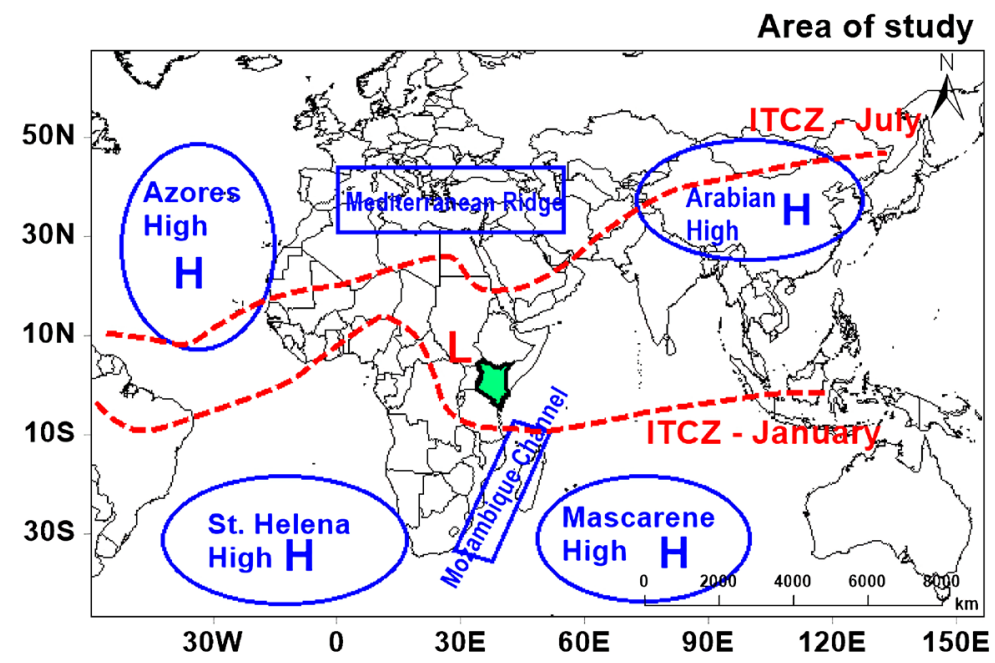

Figure 1. Geographical location of Kenya in green color. The broken red lines shows the relative position of annual movement of the Inter-Tropical Convergence Zone (ITCZ) during July and January. The blue letter $\mathrm{H}$ represent the semi-permeant high pressure cells while red letter $\mathrm{L}$ represent the low pressure region. This Map was produced on $26^{\text {th }}$ November 2018 by Misiani Zachary. 
to the eastern edge of the Rift Valley while Ngong Hills, located to the west of the city, are the most prominent geographical feature of the Nairobi region. According to Köppen climate classification (Kottek et al., 2006), the city has a subtropical highland climate especially in the months of June to July season, the evenings are cool with low temperatures of about $09^{\circ} \mathrm{C}$ and maximum of $24^{\circ} \mathrm{C}$.

ITCZ is the single most important climatic phenomenon affecting seasonality in Kenya, and its annual migration creates the 2 seasons experienced near the equator known in East Africa as the northeast (NE) and southeast (SE) monsoons. The position of the ITCZ varies predictably throughout the year. Although it remains near the equator, the ITCZ moves farther north or south over land than over the oceans because it is drawn toward areas of the warmest surface temperatures. The location of the ITCZ can vary as much as $40^{\circ}$ to $45^{\circ}$ of latitude north or south of the equator on land. It moves toward the Southern $\mathrm{He}$ misphere from September through February and reverses direction in preparation for Northern Hemisphere Summer (Chandra et al., 2018). The ITCZ is less mobile over the ocean, although there is one exception the ITCZ migrates latitudinally on a seasonal basis. In July, when the sun is over the Tropic of Cancer, the ITCZ reaches its northernmost position at about $15^{\circ} \mathrm{N}$; in January it reaches $\sim 5^{\circ} \mathrm{S}$ when the sun is over the Tropic of Capricorn. The most important consequence of this shifting is the annual alteration of wet and dry seasons in Kenya.

As shown from the area of study, there are four semi-permeant high pressure cells namely: Mascarene High to the southeast of Indian Ocean, St. Helena High in South Atlantic Ocean, and Azores High to the North Atlantic Ocean while Arabian High is situated on the Asian continent. Within these semi-permanent pressure cells, there are also Mediterranean ridge along the Mediterranean Sea and Mozambique Channel along Madagascar (Robert et al., 2008).

\subsection{Data}

The data for the above area of study was obtained from the Air Recourses Laboratory HYSPLIT MODEL http://www.ready.noaa.gov/index.php and ECMWF MODEL http://apps.ecmwf.int/datasets/data/cams.

\subsection{Methodology \& Software Used}

ArcMap 10.3.1 which is a component of ESRI's ArcGIS Geographical Information System (GIS) was utilized for drawing maps. A shapefile was created for each month from the corresponding back trajectory dataset and projected in ArcMap as an individual layer. Each data point of back trajectory shapefiles represents a geographical location in latitude and longitude degrees, height above mean sea level and time in hours before arriving to the area of study Figure 2 .

Back trajectories were also used throughout this research work to analyze the source and sinking points of air mass using ARL, HYSPLIT4 and NOAA. For the 


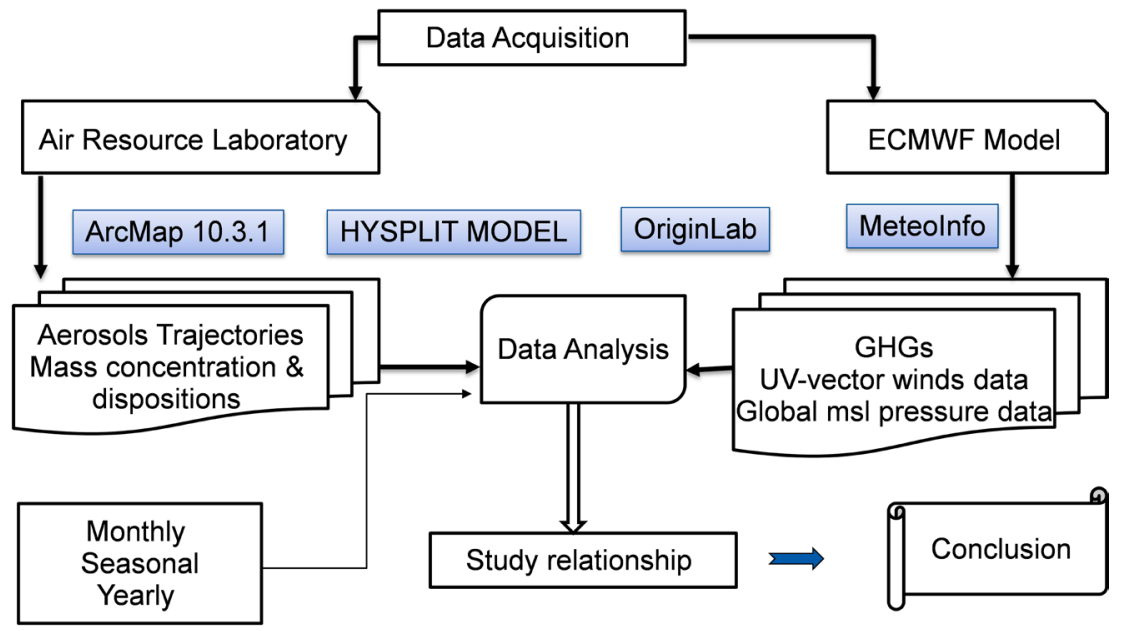

Figure 2. Methodology.

purpose of this research ECMWF was also used in conjunction with MeteoInfo and Originlab for the analysis of the mass concentration \& dispositions of the aerosols overlaid with the global UV wind vector and global mean sea level pressure data. This model is referenced with archived meteorological data for the computation of the back trajectories for six hourly data. Each trajectories that was created started at Nairobi $1.34^{\circ} \mathrm{S}$ and $36.87^{\circ} \mathrm{E}, 00 \mathrm{Z}$ time at three different levels; near surface, middle and upper levels of 1700, 2000 and 3500 meters above ground level and was calculated back 120 hours before it was exported as a GIS shapefile.

After arrangement of the data into monthly, seasonal and yearly a study relationship was done to investigate if there was any relationship between the aerosols and meteorological parameters whereby the conclusion was finally reached Figure 2.

\section{Results and Discussion}

\subsection{Monthly Trajectories Analysis}

In order to understand and monitor the major sources of aerosols arriving at Nairobi, the HYSPLIT4 model of NOAA for backward trajectories analysis was used (Draxler \& Hess, 1998). A monthly 5days back trajectories at different altitudes of 1700, 2000 and 3500 meters above mean sea level was used since the this site is at an altitude of Nairobi $1650 \mathrm{~m}$ (Zachary et al., 2018).

Generally observations show Figure 3 and Figure 4 most of the trajectories for January, February, September and December are originating from the northern hemisphere in south west direction. Most of the trajectories at the altitude of $1700 \mathrm{~m}$ and 2000 above mean sea level red and green cycles respectively starts from Saudi Arabia as it propagates through Yemen, Somalia, and Indian Ocean then enters into Kenya at the border of Somalia and Kenya through arid and semi-arid northeastern province Figure 3(a), Figure 3(b), Figure 3(i), and Figure 3(1) (Zachary et al., 2018). This was predominantly due to North east 
monsoon that is occasioned by intensification of the Arabian Ridge when northern hemisphere is experiencing winter season, and there is higher pressure gradient
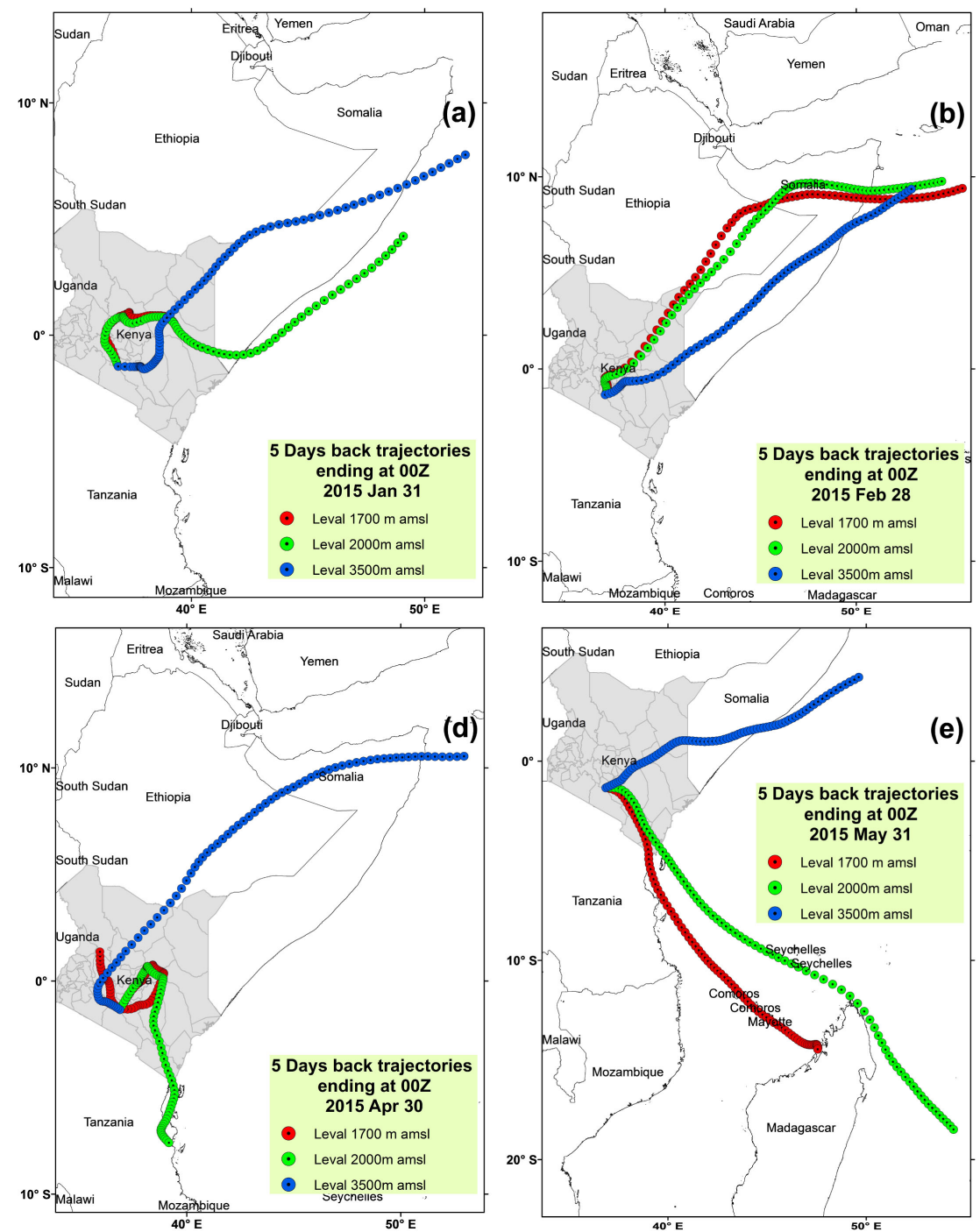

(d)
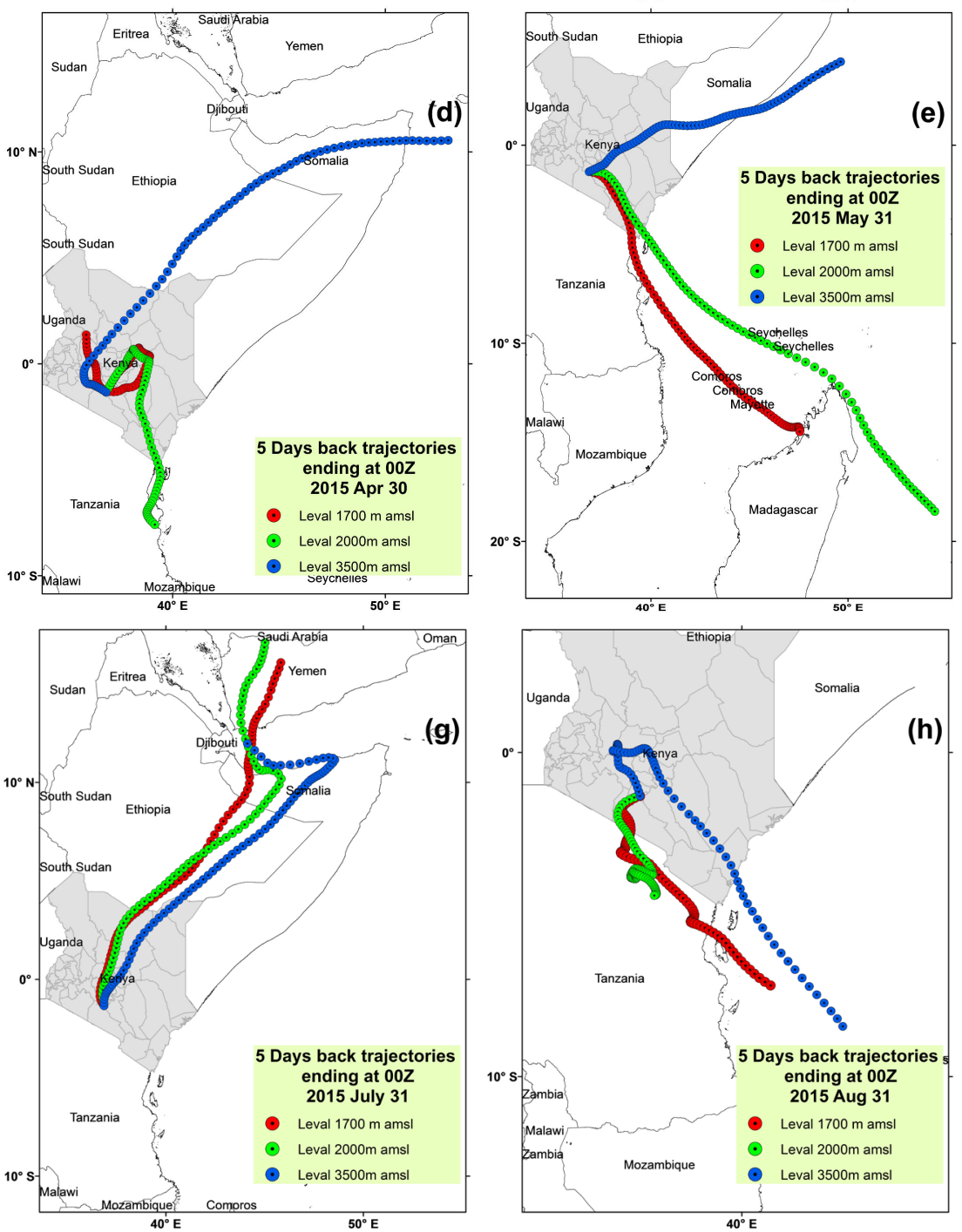
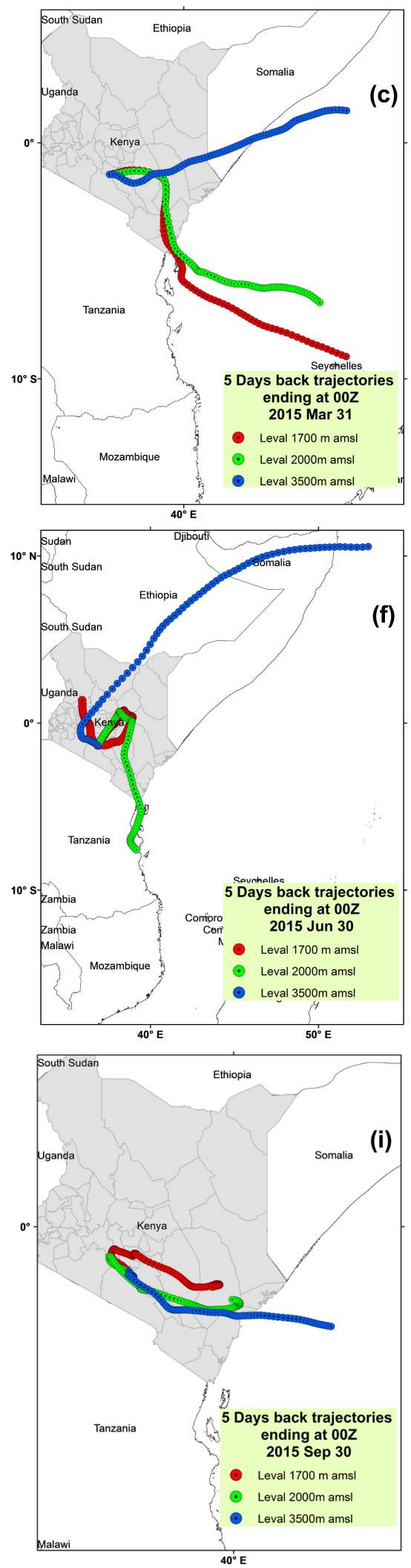

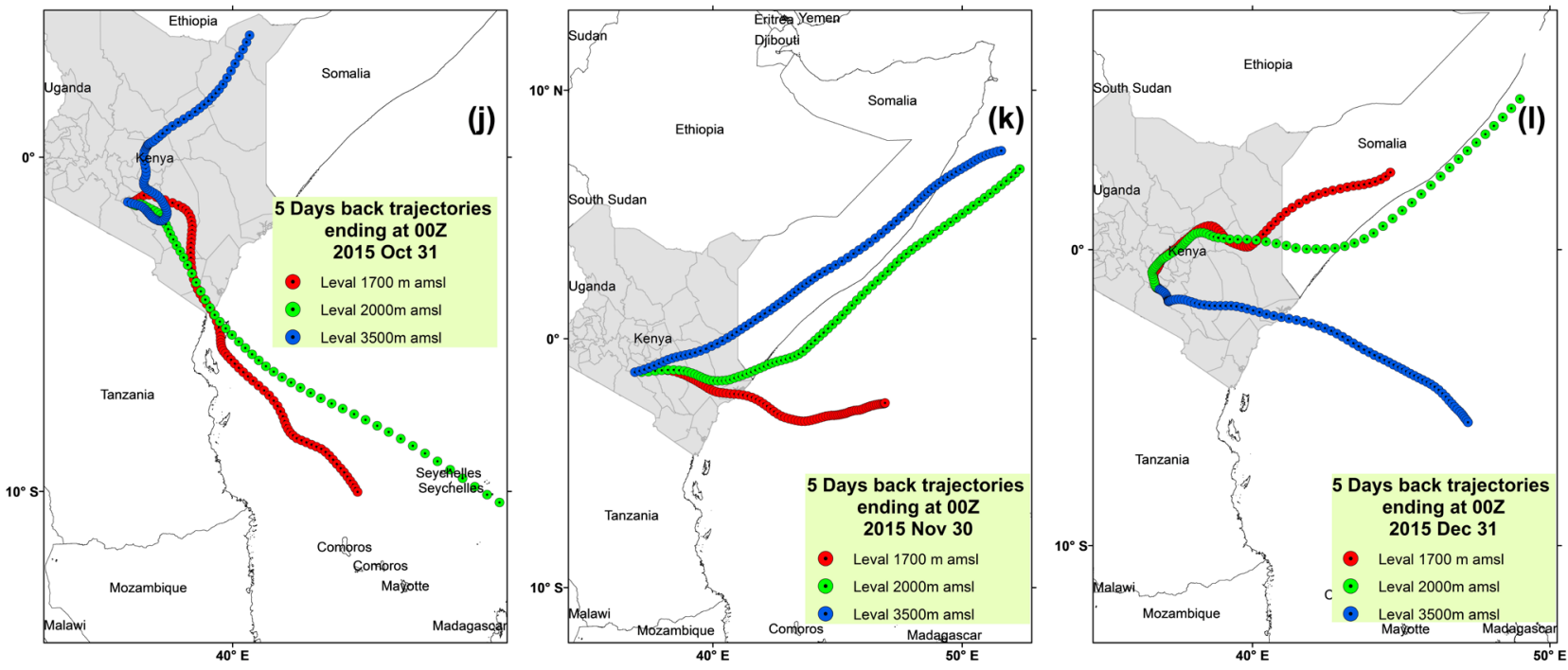

Figure 3. Typical five day HYSPLIT-4 backward trajectories analysis results ending at $00 \mathrm{Z}$ over Nairobi $\left(1.34^{\circ} \mathrm{S}, 36.87^{\circ} \mathrm{E}, 1650\right.$ above mean sea level (AMSL)) at different altitude of 1700 (red line), 2000 (green line) and 3500 (blue line) meters above mean sea level on monthly for 2015. (a) to (l) represent January to December respectively.
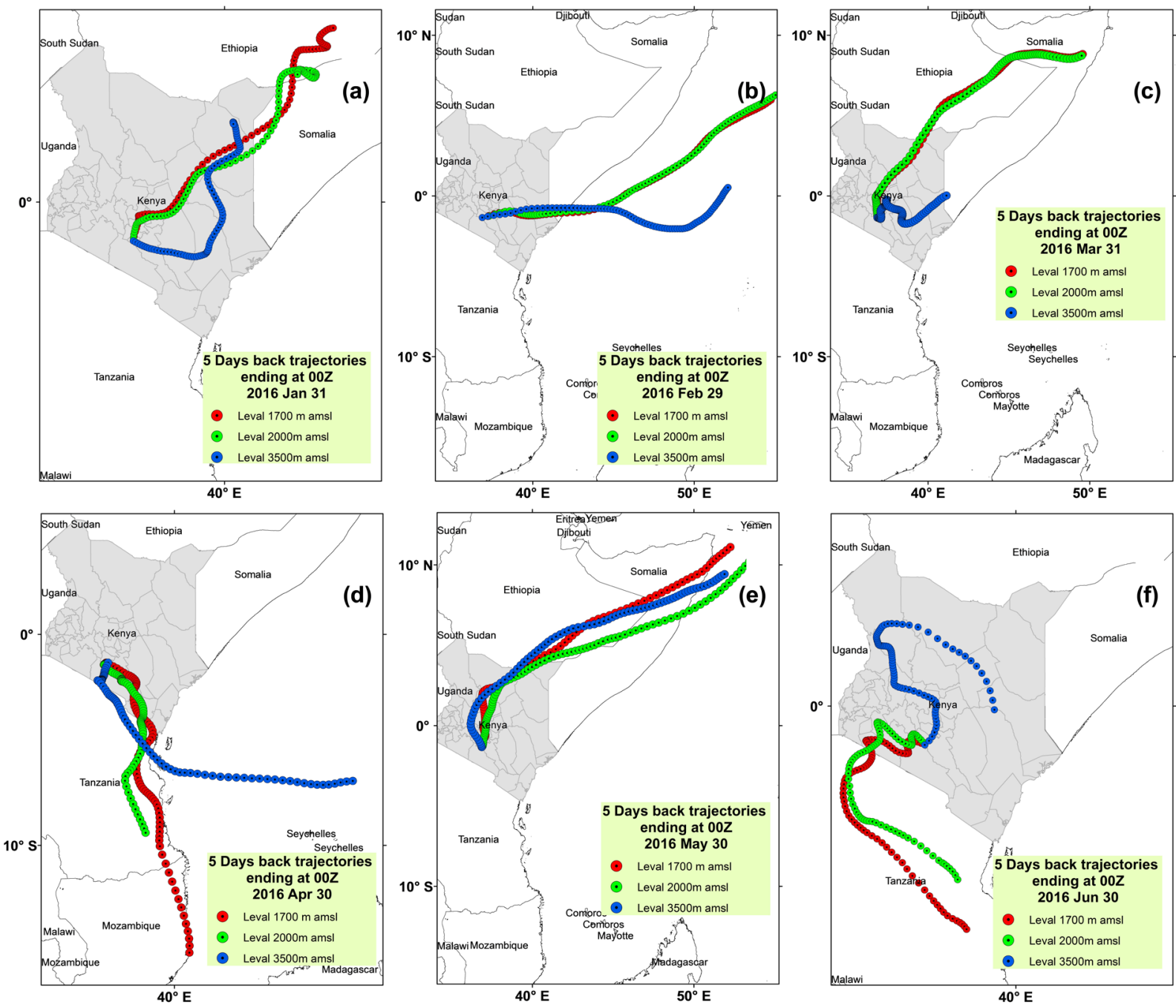

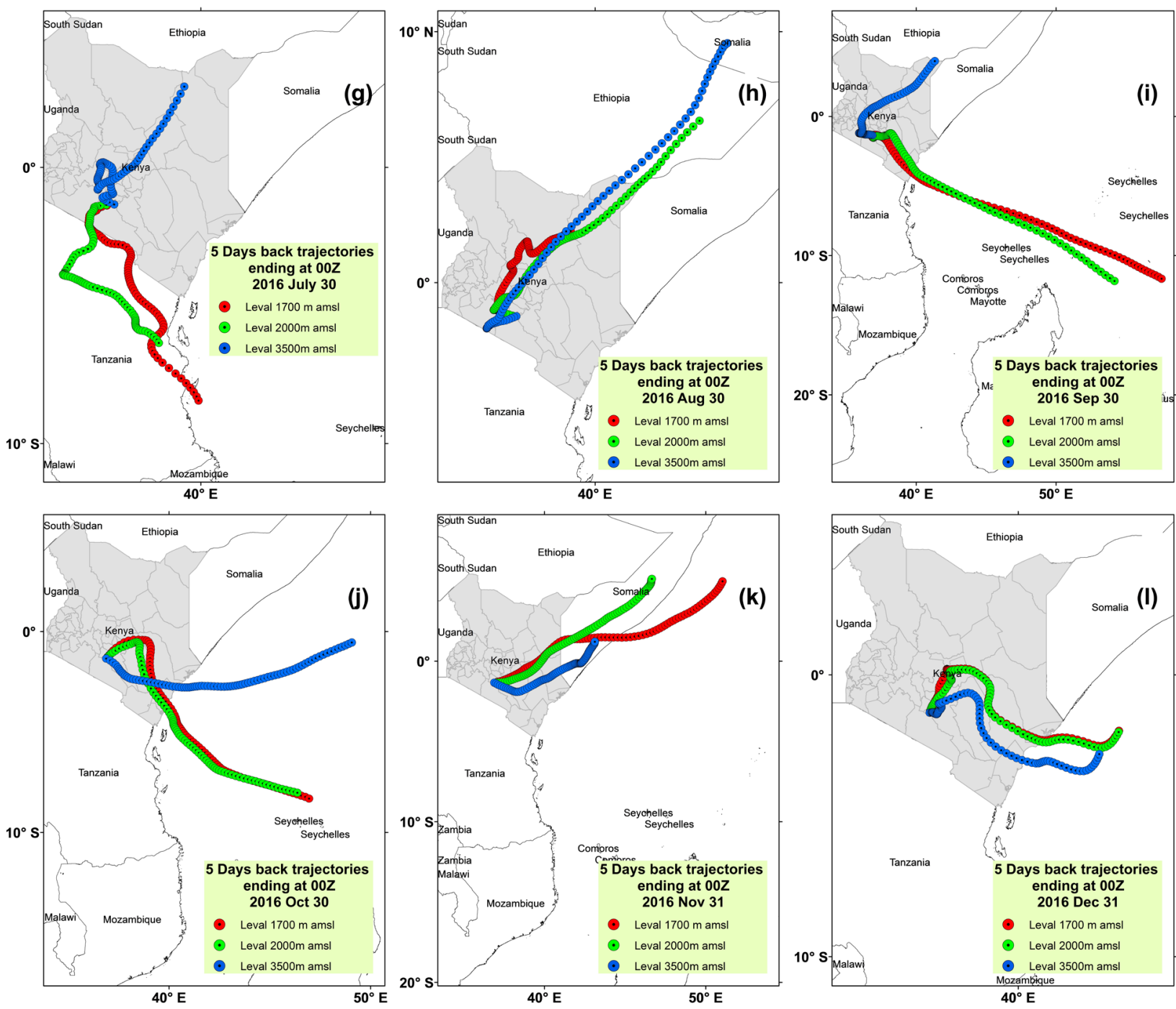

Figure 4. Typical five day HYSPLIT-4 backward trajectories analysis results ending at $00 \mathrm{Z}$ over Nairobi $\left(1.34^{\circ} \mathrm{S}, 36.87^{\circ} \mathrm{E}, 1650\right.$ above mean sea level (AMSL)) at different altitude of 1700 (red lines), 2000 (green lines) and 3500 (blue lines) meters above mean sea level on monthly for 2016. (a) - (l) represent January to December respectively.

from northern hemisphere to southern hemisphere which create general flow of NE monsoon winds from north to south (Simiyu et al., 2018).

During the wet seasons of March-May (MAM) and September-November (SON), the air mass trajectories origin was easterly which indicates the presence of the ITCZ over Kenya. From the trajectory distribution, there is a general easterly component whereby the trajectories are oscillating generally from easterly to southeasterly component which follows the position of the ITCZ Figure 3(c), Figure 3(d), Figure 3(j), Figure 3(k), Figure 4(c), Figure 4(e), Figure 4(i), Figure 4(j) and Figures 5(c)-(e), Figure 5(k).

During dry season of JJA when the northern hemisphere is experiencing summer, the dominant winds over Nairobi is generally between southerly and southeasterly direction. The trajectories originate from far Indian Ocean as it propagates through Madagascar Island. Through the application of a simple 
techniques of wind analysis it can be seen that a persistent high-speed of winds of about (15 to 25) knots in the form of low level jet stream exists in the lower
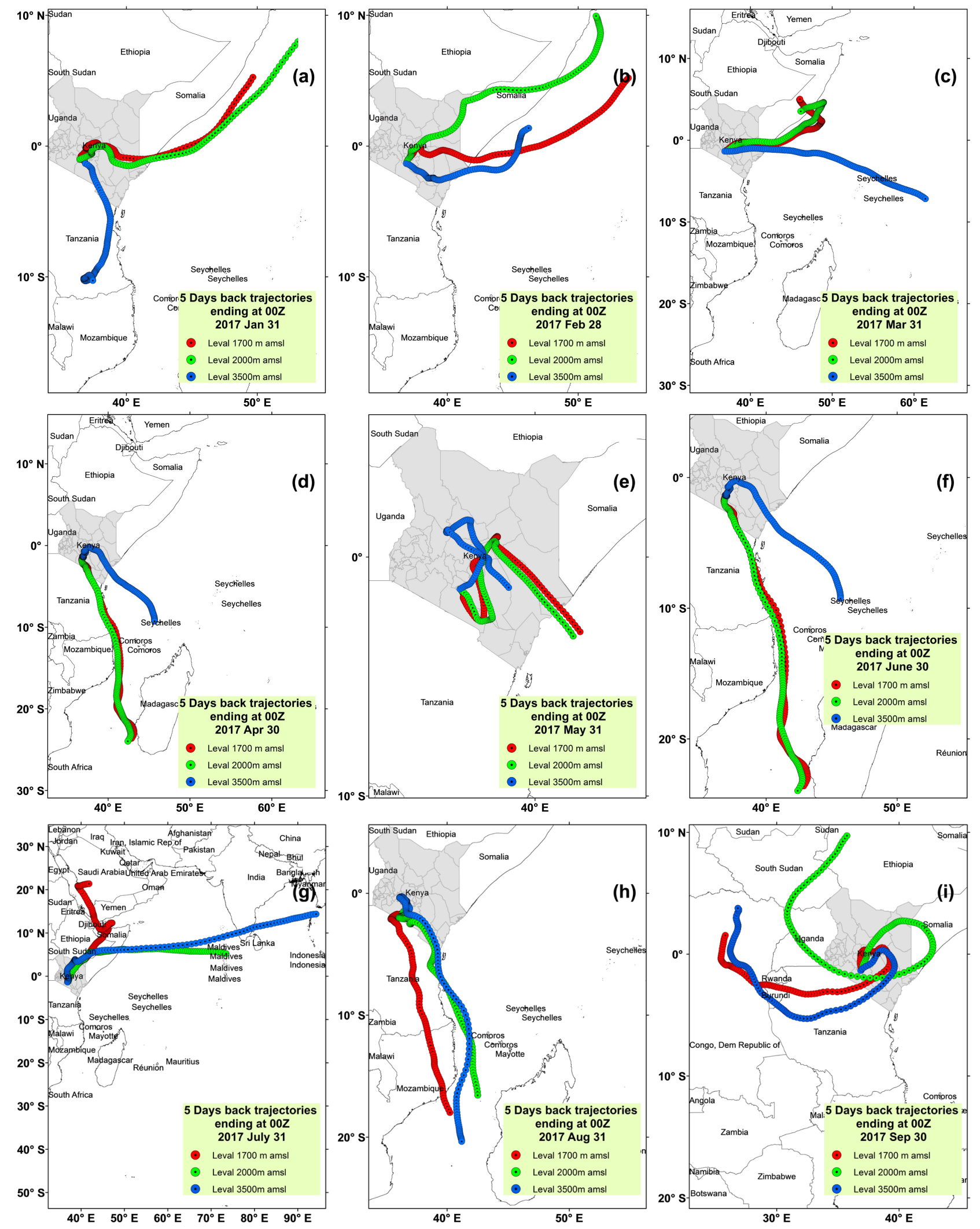

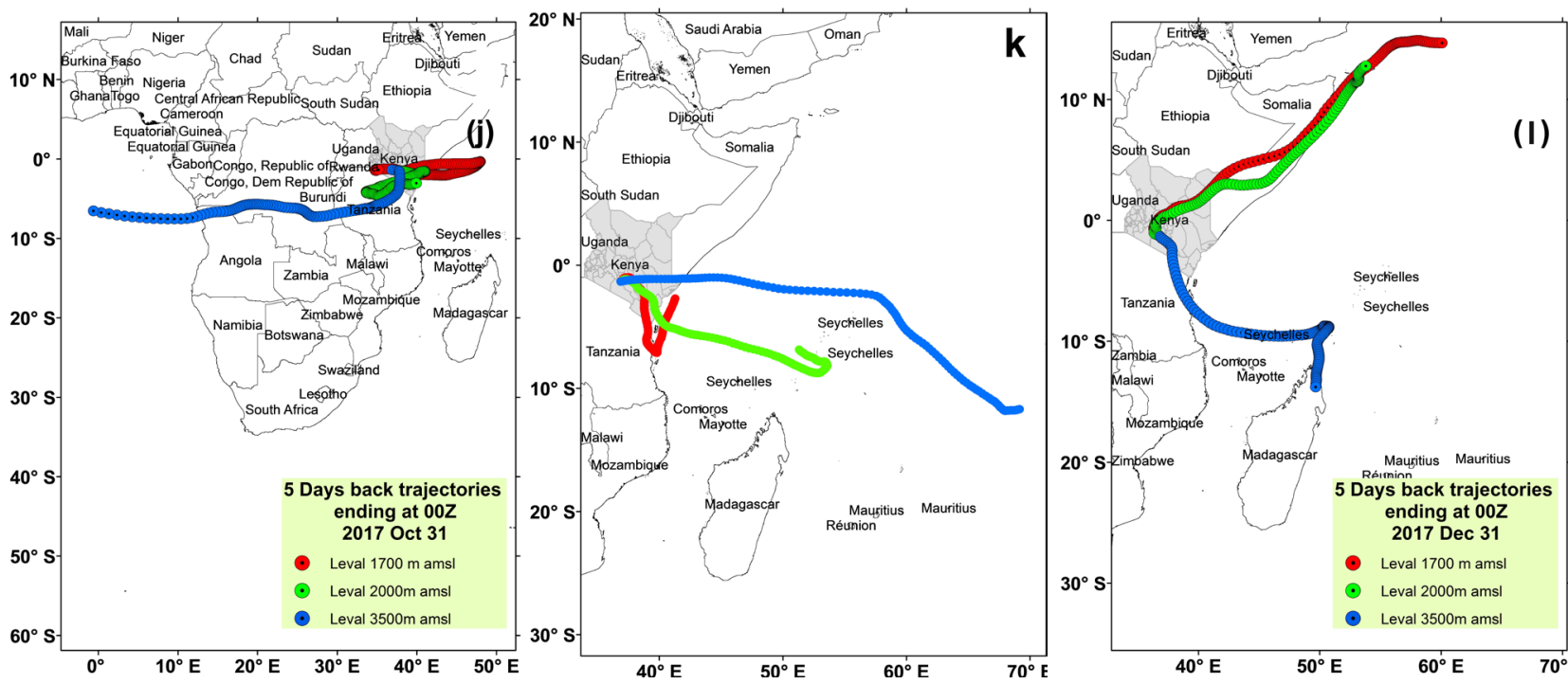

Figure 5. Typical five day HYSPLIT-4 backward trajectories analysis results ending at $00 \mathrm{Z}$ over Nairobi $\left(1.34^{\circ} \mathrm{S}, 36.87^{\circ} \mathrm{E}, 1650\right.$ above mean sea level (AMSL)) at different altitude of 1700 (red lines), 2000 (green lines) and 3500 (blue lines) meters above mean sea level on monthly for 2017. (a) - (l) represent January to December respectively.

layers which originates from the tip of Madagascar Island to reach the Kenyan coastline as southerly (Zachary et al., 2018). This winds turn to Southwest upon crossing the equator. As this maritime winds passes through steep eastern mountain slopes of Madagascar, most of its water vapor is retained in the lower layers, hence this air masses become dry with more sea salt particles and dust. The narrow fetch of Mozambique Channel Figure 1 does not allow this air masses to replace the lost moisture. The upper convergence along the equatorial region during July leads to the sinking motion of the aerosols particles into the area of interest and also due to the effect of topographical intensification of the flow, the speed is generally reduced as winds converges into western parts of Kenya leading to more concentration of sea salts and dust particles to the area of study.

\subsection{Monthly Concentration \& Dispositions Analysis}

HYSPLIT aerosols mass concentration maps Figures 6-8 it can be inferred that both nearby and far source areas such as Somalia, Indian Ocean and Madagascar Island contributed to the atmospheric aerosols arriving to Nairobi. The concentration distribution as shown by the wind analysis maps is a general distribution of aerosols follows the general flow of winds. During the months of December-February, North East Monsoon-(NEM) winds are dominate to the area of study. This results of the general wind flow portrays other results from same (Muhati et al., 2007) which showed that most easterlies winds are dominant winds the months of January and November over Nairobi. NEM starts from Himalayas and also due to westerly depression then it travel towards South West as it passes through the Arabian sea and ends up in the Indian Ocean as it closes equator. The dry winds from the north carries both fine mode and coarse mode 
aerosols particles, travels towards the Indian Ocean there they may pick up sea salts particles and moisture.

During the wet seasons March-April-May (MAM) and September-OctoberNovember (SON) Figure 6, Figure 7 and Figures 8(b)-(d), Figures 8(i)-(k) the South East Monsoon (SEM) winds flows southeast direction from Indian
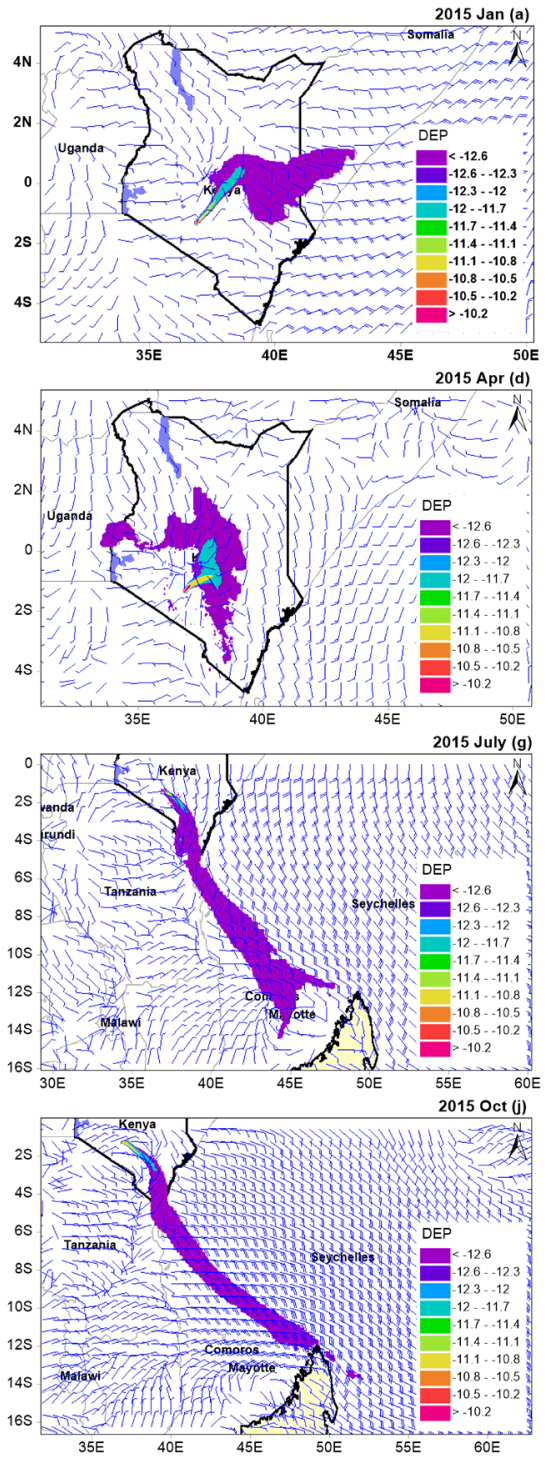
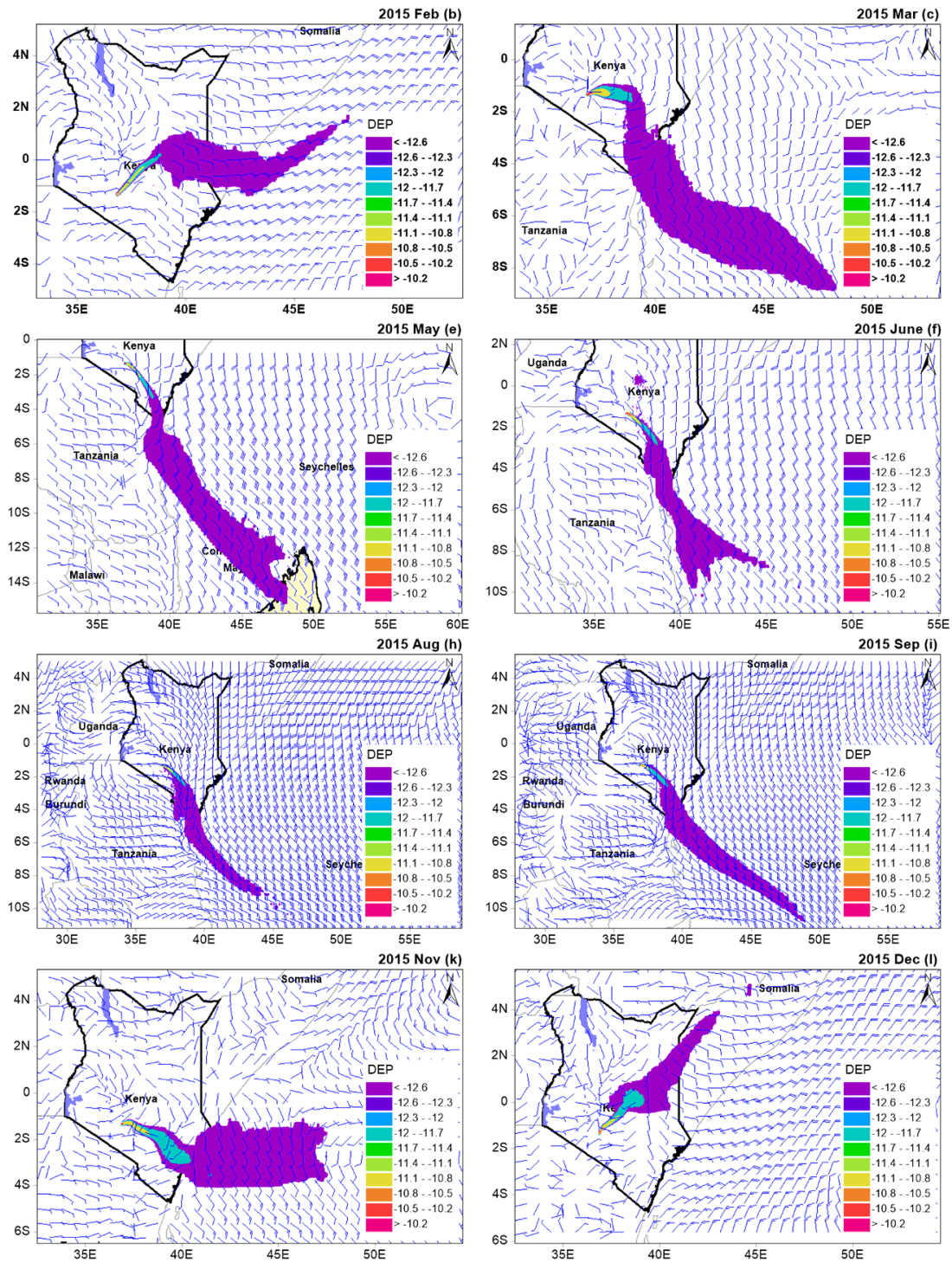

Figure 6. HYSPLIT aerosols mass loading concentration (mass $/ \mathrm{m}^{3}$ ) between 0 and $1650 \mathrm{~m}$ above mean sea level (AMSL) for monthly average 2015 .
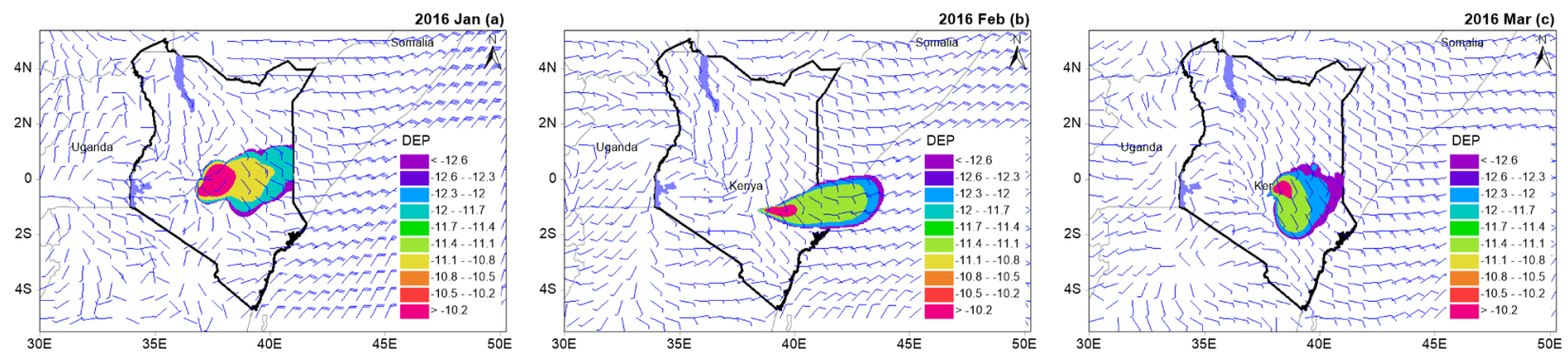

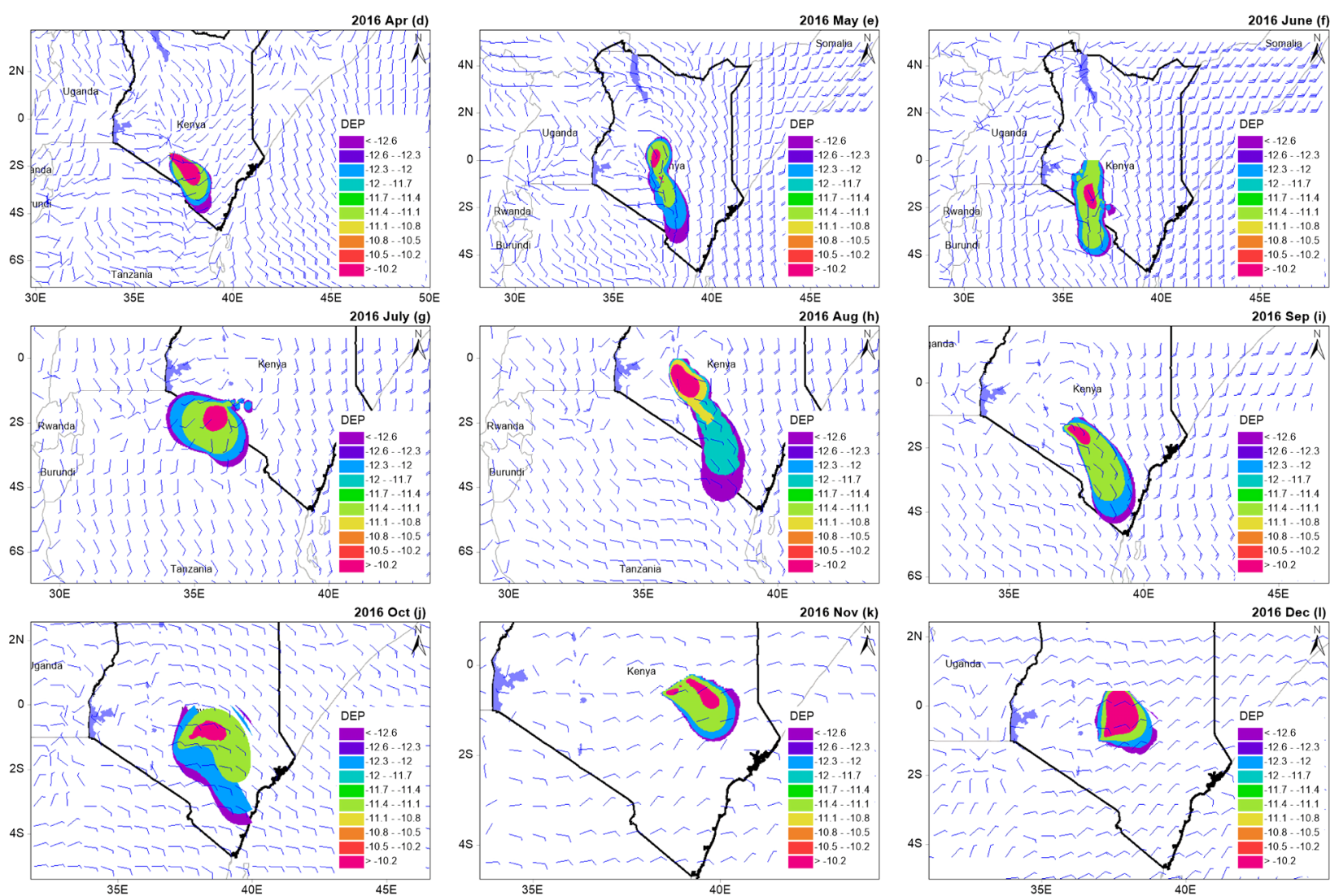

Figure 7. HYSPLIT aerosols mass loading concentration $\left(\mathrm{mass} / \mathrm{m}^{3}\right.$ ) between 0 and $1650 \mathrm{~m}$ above mean sea level (AMSL) for monthly average 2016 .

Ocean. So during this period along with the wind movement the pollutants travel and spread its effects accordingly. The monsoon fetches sea salt pollutants and dust particles along with its moisture from Indian Ocean and sheds the polluted rain water in various part of Kenya. April is the perk month during the long rain season, as it can be seen from the Figure 6, Figure 7 and Figure 8(c) mostly aerosols comes from nearby surrounding areas as compared to other months.

With the oscillation of the winds between Northeast, east, southeast and south, there is a great contribution of pollution when the trajectories are Easterlies and Southerlies and mostly during hot-dry season of DJF \& cold-dry JJA season. Dry seasons having less rainfall washout effect most of the pollutants this time are highest.

\subsection{Mean Sea Level Surface Pressure and Global Wind Flow}

In general, the global atmospheric pressure belts shift northward in July Northern Hemisphere summer and southward in January Southern Hemisphere summer following the changing position of the sun's direct rays as they migrate between the Tropical of Cancer and Tropical Capricorn (Okoola \& Raphael, 1999). During Northern Hemisphere winter (DJF), the Arabian High and Azores High pressure cells have a higher pressure of $1030 \mathrm{hPa}$ compared to Southern 

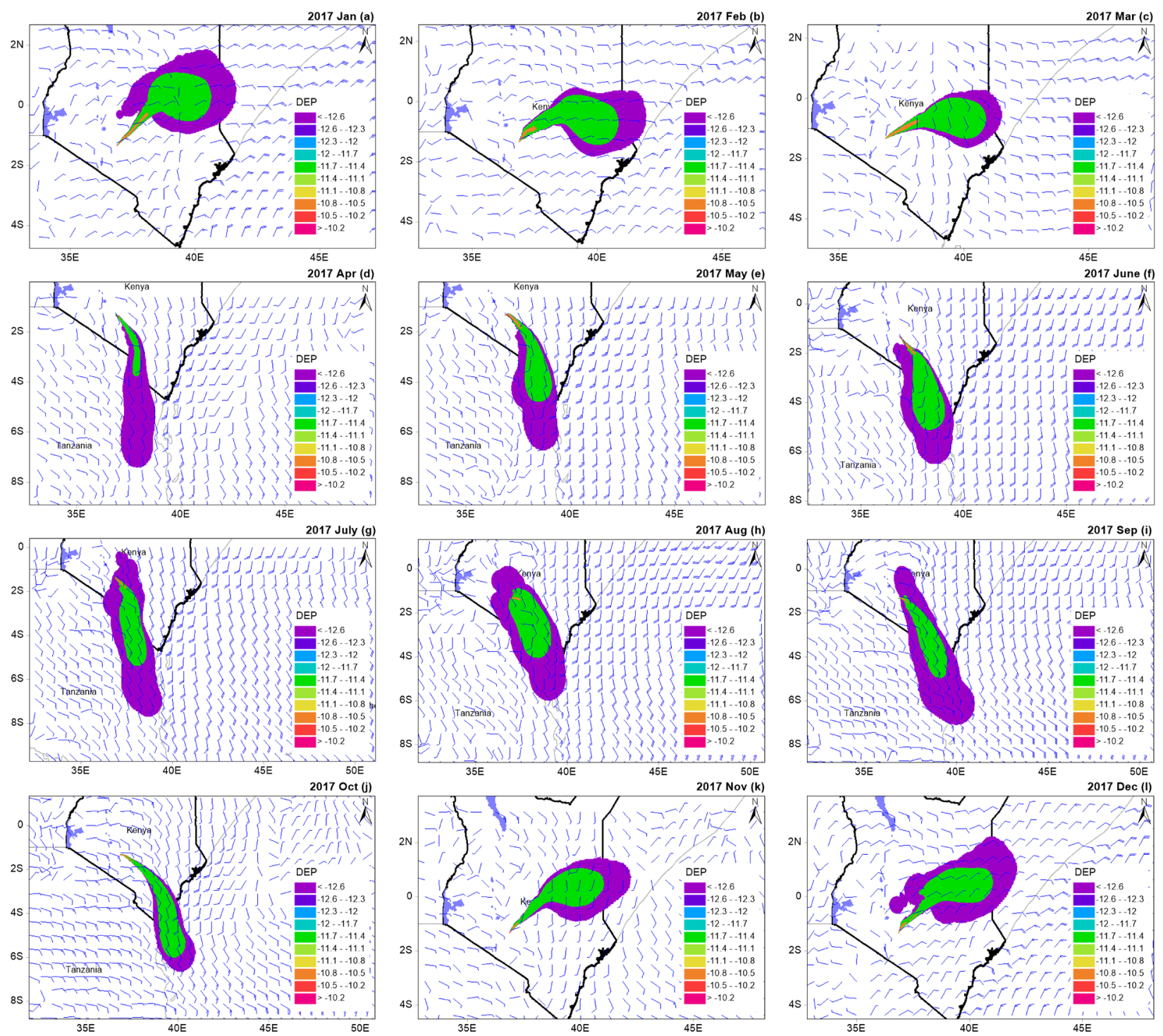

Figure 8. HYSPLIT aerosols mass loading concentration (mass $/ \mathrm{m}^{3}$ ) between 0 and $1650 \mathrm{~m}$ above mean sea level (AMSL) for monthly average 2017.

Hemisphere Mascarene and St. Helena 1020 hPa Figures 9-11 January. This leads to the development of a pressure graduate from north to south. Because of the Coriolis Effect, the northern trade winds move away from the subtropical high in a clockwise direction out of the northeast Figure 9 January, Figure 10 January and Figure 11 January. The air mass during this season passes over the drier India, Saudi Arabia, Yemen, and Somalia land mass and therefore it carries a lot of dust particles toward Kenya (McClanahan, 1988; Zachary et al., 2018).

Over eastern Asia, there is a strongly developed anticyclone during the winter months that is known as the Arabian High. It can be seen that NE monsoons dominate during the Southern Hemisphere summer (December-February), while the SE monsoons are observed during the Northern Hemisphere summer (June-August) Figure 9 July, Figure 10 July and Figure 11 July. (Chandra et al., 2018). 

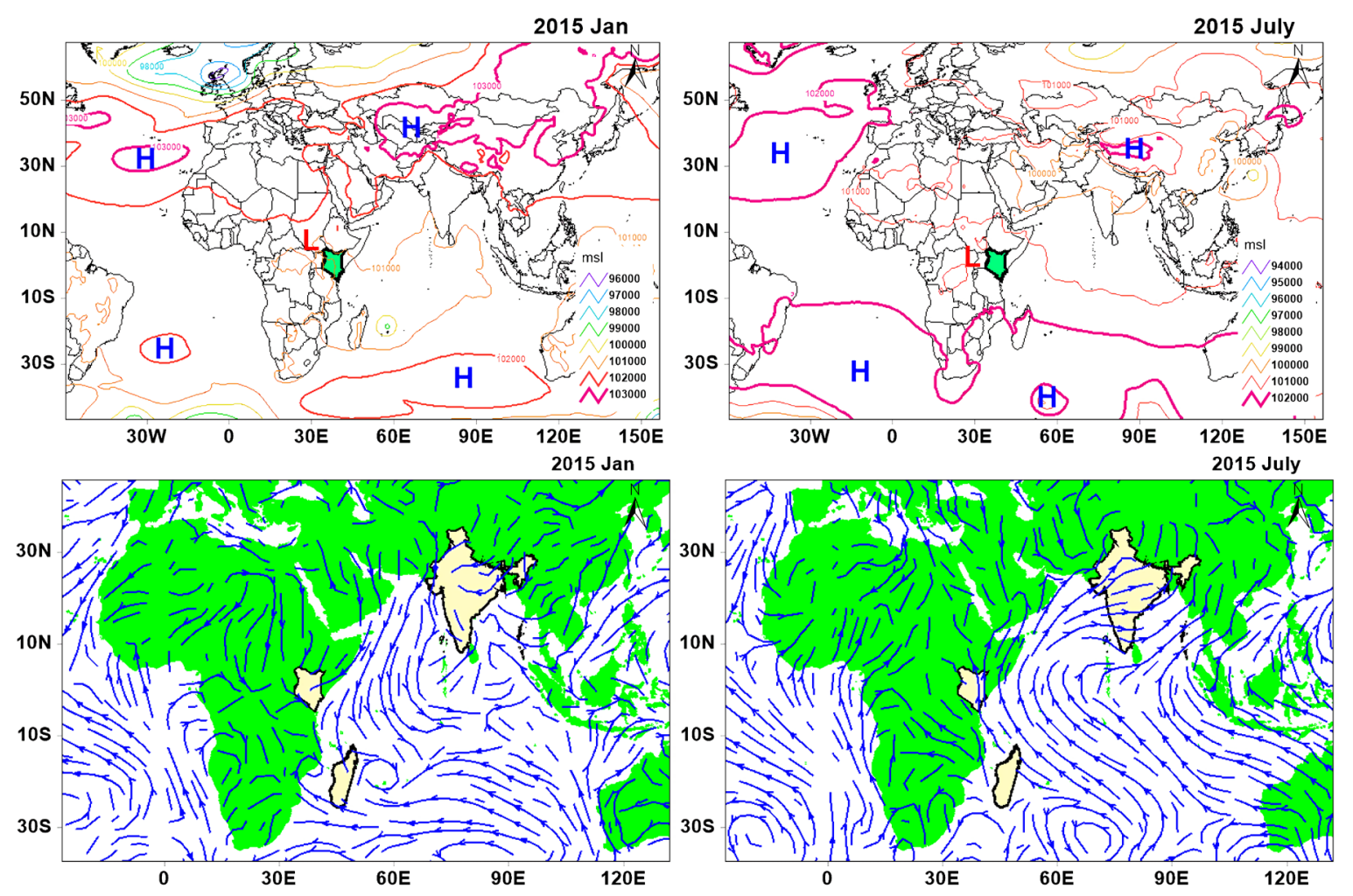

Figure 9. Average sea-level pressure (in bars) and global streamlines wind flow, winter in the Northern Hemisphere (January) and summer Northern Hemisphere (July) 2015.
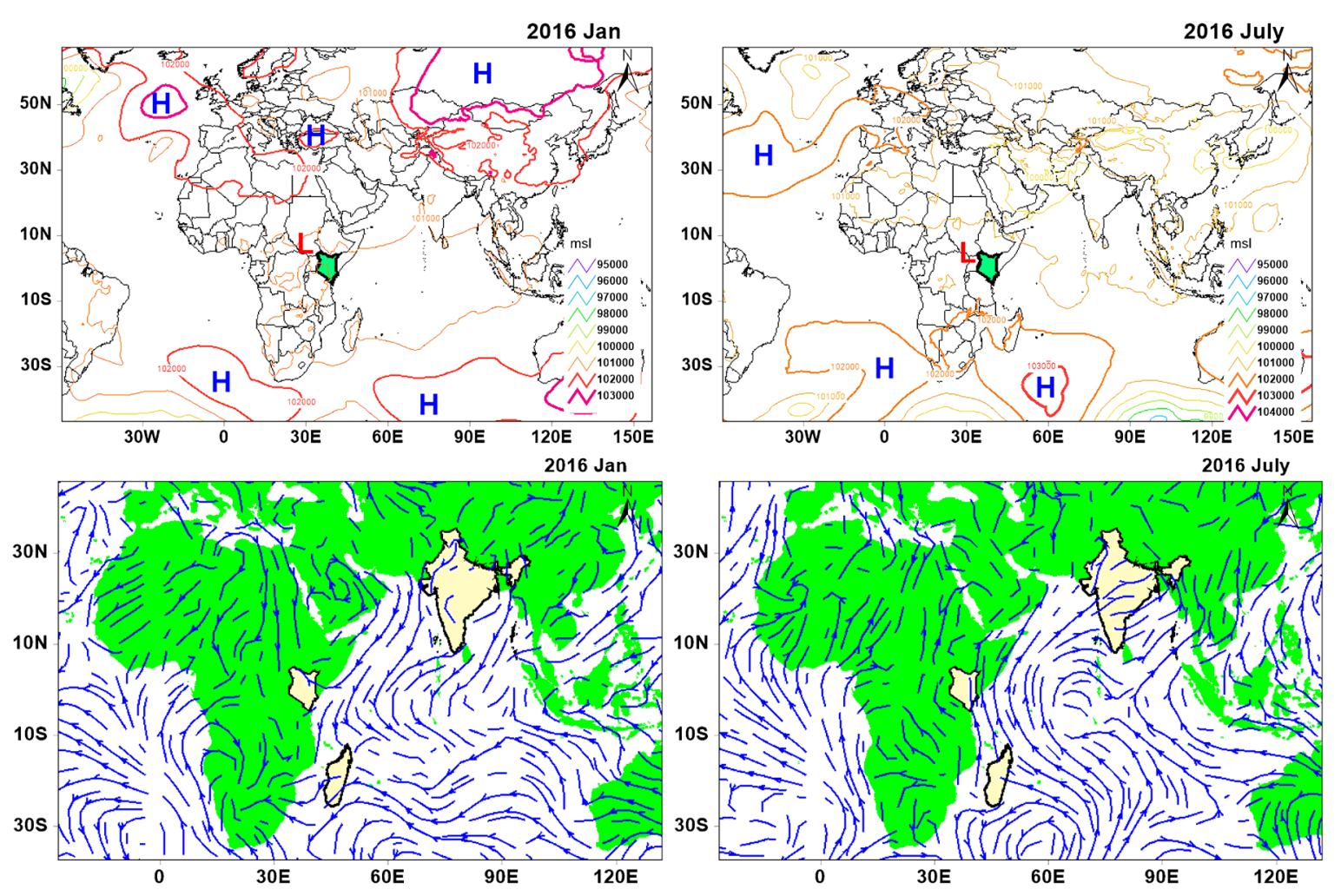

Figure 10. Average sea-level pressure (in bars) and global streamlines wind flow, winter in the Northern Hemisphere (January) and summer Northern Hemisphere (July) 2016. 

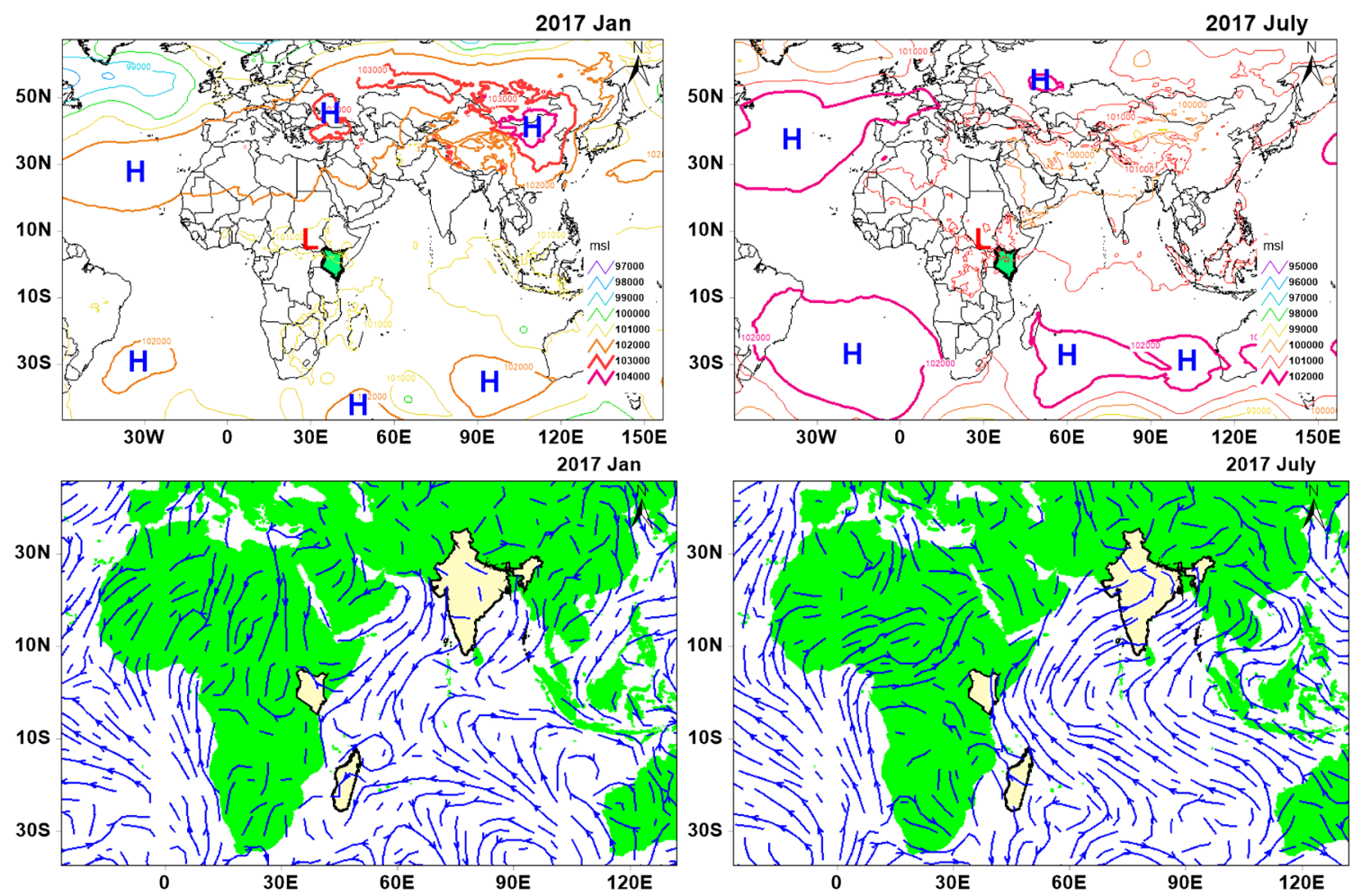

Figure 11. Average sea-level pressure (in bars) and global streamlines wind flow, winter in the Northern Hemisphere (January) and summer Northern Hemisphere (July) 2017.

During JJA, the Southern Hemisphere experiences winter season while Northern Hemisphere there is summer. The Mascarene High and St. Helena High pressure cells become stronger than the pressure in the Northern Hemisphere of Azores and Arabian High. This lead to the creation of pressure gradient from south to north. The anticyclone over the North Pole is greatly weakened during the summer months in the Northern Hemisphere, primarily because of the lengthy (24-hour days) heating of the oceans and landmasses in that region while the land-masses, which developed high pressure cells during the cold winter months, have extensive low pressure cells slightly to the south during the summer. This creates South East Monsoon winds. This monsoon winds passes through Madagascar Island and Indian Ocean carries dust aerosols and sea salt along with toward Kenya Figures 6-8 JJA (Zachary et al., 2018).

A transition period occurs from the NE to SE monsoons during the period of the Northern Hemisphere spring and autumn seasons. During March-May and October-November periods, Kenya received long rains and short rains respectively. This transition is characterized by convergence of low-level equatorward moving air masses from both hemispheres. These low-level air masses constitute the monsoonal flows and the zone of convergence is the ITCZ.

\section{Summary and Conclusion}

Seasonal weather variation plays a critical role in the monthly variations of aerosols in Kenya. We have likewise demonstrated that there is a strong rela- 
tionship between atmospheric pressure, winds and 120-hour back trajectories. Monthly variation of aerosols occurrence was definitely non-uniform, as aerosols were mostly concentrated in the hot and dry seasons of JJA and DJF. While in wet seasons of MAM and OND, most aerosols were removed from the atmosphere through wet scavenging process.

The majorities of trajectories, mass concentration and disposition of aerosols are azimuthally confined in wide intervals of $045^{\circ}-180^{\circ}$ on angle composs direction, indicating that a northeasterly distribution of aerosols transport was prominent during northern hemisphere winter (DJF) while southeasterly distribution of aerosols transport was prominent during southern hemisphere winter season JJA.

The results also indicate that back trajectories, mass concentration and disposition is positively correlated with general flow of winds governed by pressure gradient from both hemisphere. It is apparent that seasonality is a major factor affecting annual patterns of aerosols in Kenya. The annual migration of ITCZ northward and southwards from the equator, the changes of atmospheric pressure from the semi-permanent high pressure cells which creates pressure graduate, monsoon winds were the important factors for the atmospheric aerosols transportation in Kenya.

\section{Future Work}

Our findings here that both trajectory and air mass are acting in tandem to influence aerosols transportation from source-sink region. We strongly encourage other researchers to investigate the joint relationship between air mass, temperature, humidity and back trajectories including other pollutant species like $\mathrm{O}_{3}$, $\mathrm{PM}, \mathrm{SO}_{2}$, and $\mathrm{CO}$ over the same region.

\section{Acknowledgements}

The authors wish to extend their sincere gratitude to the Principal Investigators and their staff in establishing and maintaining the AERONET site and for providing online data. We also owe our sincere thanks to the NOAA Air Resources Laboratory for computing back trajectories using the HYSPLIT4 model. This paper supported by The Innovative Research Group for Nationalities's Development of Yunnan, Yunnan Academy of Social Sciences, China and The National Social Science Fund of China "Research on the Driving Force of Native Culture in Ecological Poverty Alleviation at Southwest Ethnic Areas" (SN: 16BMZ082) 2016.

\section{Conflicts of Interest}

The authors declare there is no any conflict of interest regarding the publication of this paper.

\section{References}

Asman, W. A. H. (1995). Parameterization of Below-Cloud Scavenging of Highly Soluble 
Gases under Convective Conditions. Atmospheric Environment, 29, 1359-1368.

Beukes, J. P., Vakkari, V., Van Zyl, P. G., Venter, A. D., Josipovic, M., Jaars, K., Tiitta, P., Kulmala, M., Worsnop, D., Pienaar, J. J., Virkkula, A., \& Laakso, L. (2013). Source Region Plume Characterization of the Interior of South Africa as Observed at Welgegund, Clean Air Journal, 23, 7-10.

Chandra, B., Viswavidyalaya, K., \& Bengal, W. (2018). Winds and Global Circulation of Winds.

Draxler, R. R., \& Hess, G. D. (1998). An Overview of the HYSPLIT_4 Modelling System for Trajectories. Australian Meteorological Magazine, 47, 295-308.

Draxler, R. R., \& Rolph, G. D. (2013). HYSPLIT (HYbrid Single-Particle Lagrangian Integrated Trajectory) Model Access via NOAA ARL READY Website. NOAA Air Resources Laboratory, Silver Spring. http://ready.arl.noaa.gov/HYSPLIT.php

Gabler, R. E., Petersen, J. F., \& Trapasso, L. M. (2008). Atmospheric Pressure, Winds, and Circulation Patterns (pp. 113-137).

Ha, R., Baatar, A., \& Yu, Y. (2017). Identification of Atmospheric Transport and Dispersion of Asian Dust Storms. Natural Hazards and Earth System Sciences, 17, 1425-1435. https://doi.org/10.5194/nhess-17-1425-2017

Isaksen, I. S. A., Granier, C., Myhre, G., Berntsen, T. K., Dalsoren, S. B., Gauss, M., Klimont, Z., Benestad, R., Bousquet, P., Collins, W., Cox, T., Eyring, V., Fowler, D., Fuzzi, S., Jockel, P., Laj, P., Lohmann, U., Maione, M., Monks, P., Prevot, A. S. H., Raes, F., Richter, A., Rognerud, B., Schulz, M., Shindell, D., Stevenson, D. S., Storelvmo, T. Wang, W. C., van Weele, M., Wild, M., \& Wuebbles, D. (2009). Atmospheric Composition Change: Climate-Chemistry Interactions. Atmospheric Environment, 43, 5138 5192. https://doi.org/10.1016/j.atmosenv.2009.08.003

Jaffe, D., Anderson, T., Covert, D., Kotchenruther, R., Barbara, B., Danielson, J., Simpson, W., Bernsten, T., Karlsdottir, S., Blake, D., Harris, J., Carmichael, G., \& Uno, I. (1999). Transport of Asian Air Pollution to North America. Geophysical Research Letters, 26, 711-714. https://doi.org/10.1029/1999GL900100

Kottek, M. et al. (2006). World Map of the Köppen-Geiger Climate Classification Updated. Meteorologistche Zeitschrift, 15, 259-263.

Levy, R. C. et al. (2007). Second-Generation Operational Algorithm: Retrieval of Aerosol Properties over Land from Inversion of Moderate Resolution Imaging Spectroradiometer Spectral Reflectance. Journal of Geophysical Research Atmospheres, 112, 1-21.

Mahowald, N. M., Zender, C. S., Luo, C., Savoie, D., Torres, O., \& del Corral, J. (2002). Understaning the 30-Year Barbados Desert Dust Record. Journal of Geophysical Research, 107, 4561.

McClanahan, T. R. (1988). Seasonality in East Africa's Coastal Waters. Marine Ecology Progress Series, 44, 191-199. https://doi.org/10.3354/meps044191

Muhati, F. D., Ininda, J. M., \& Opijah, F. J. (2007). Relationship between ENSO Parameters and the Trends and Periodic Fluctuations in East African Rainfall. Journal of Kenya Meteorological Society, 1, 20-43.

Okoola, R. E. (1999). A Diagnostic Study of the Eastern Africa Monsoon Circulation during the Northern Hemisphere Spring Season. International Journal of Climatology, 19, 143-168. https://doi.org/10.1002/(SICI)1097-0088(199902)19:2<143::AID-JOC342>3.0.CO;2-U

Shao, M., Tang, X. Y., Zhang, Y. H., \& Li, W. J. (2006). City Clusters in China: Air and Surface Water Pollution. Frontiers in Ecology and the Environment, 4, 353-361.

Simiyu, A. H., Muthama, J., \& Ngaina, J. (2018). Anthropogenic Contribution to Air Pol- 
lution with Background Emissions; Case of Nairobi, Mombasa and Kisumu. International Journal of Scientific and Research Publications, 8, 380-402.

Stein, A. F., Draxler, R. R., Rolph, G. D., Stunder, B. J. B., Cohen, M. D., \& Ngan, F. (2015). NOAA's HYSPLIT Atmospheric Transport and Dispersion Modeling System. Bulletin of the American Meteorological Society, 96, 2059-2077. https://doi.org/10.1175/BAMS-D-14-00110.1

Tegen, I., \& Fung, I. (1994). Modeling of Mineral Dust in the Atmosphere: Sources, Transport, and Optical Thickness. Journal of Geophysical Research, 99, 22897-22914. https://doi.org/10.1029/94JD01928

Twomey, S. (1977). Influence of Pollution on Shortwave Albedo of Clouds. Journal of the Atmospheric Sciences, 34, 1149-1152. https://doi.org/10.1175/1520-0469(1977)034<1149:TIOPOT>2.0.CO;2

Van Pinxteren, D. et al. (2010). A GIS Based Approach to Back Trajectory Analysis for the Source Apportionment of Aerosol Constituents and Its First Application. Journal of Atmospheric Chemistry, 67, 1-28. https://doi.org/10.1007/s10874-011-9199-9

Walker, J. T., Aneja, V. P., \& Dickey, D. A. (2000). Walker Atmospheric Transport and Deposition of Ammonium in North Carolina. 34, 3407-3418.

Zachary, M., Niu, S., \& Lü, J. (2018). Aerosol Optical and Micro-Physical Characteristic Derived from AERONET in Kenya. Open Access Library Journal, 5, 1-16. https://doi.org/10.4236/oalib.1104551

Zachary, M., Yin, L., \& Zacharia, M. (2018). Aerosol Optical Depth Pathways and Sources; Lake Victoria Basin. Open Access Library Journal, 5, e4393. https://doi.org/10.4236/oalib.1104393

Zhang, Y. F. et al. (2016). Current Research Trend on Urban Sewerage System in China Yun-Fang. 2nd International Conference on Advances in Energy Resources and Environment Engineering, IOP Conf. Series: Earth and Environmental Science, 59, 427-436. 